\title{
THE ROLE OF NEOLOGISMS IN THE LANGUAGE OF MODERN MEDIA
}

\author{
Muhlisaxon Kurbanova
}

Undergraduate Student, National University Of Uzbekistan Named After Mirzo Ulugbek, Tashkent, Uzbekistan Sevara Sultanova

Lecturer, Department Of Russian Language, Ferghana State University, Ferghana, Uzbekistan

\section{ABSTRACT}

At this stage of the development of Russian studies, the study of not only the lexical system itself is characteristic. A study of processes, the study of which is engaged in neology, considering the emergence of new words, new trends in word formation, stylistic compatibility of neologisms, etc. becomes relevant.

KEYWORDS: - Neologisms, linguists, mass media, significant part, journalistic style.

\section{INTRODUCTION}

In the context of the functioning of the language, the formation of new words is an ongoing process, which supports the constant interest of linguists in the problems of neologisms. Their studies are conducted in various fields: word-education, sociolinguistic, psycholinguistic, typological, etc.

Changes taking place in society are depicted primarily in the media. We can say that at first neologisms appear in the press.

Most neologisms are found in business publications, such as Kommersant, etc. Economic terms are best known here, for example «рецессия», «инвестор» (Article "Alarm Sign."). There are also composite names "double recession," «бивалютная корзина». The newspaper Arguments and Facts, which positions itself as a mass publication for the whole family, shows both interstitial neologisms (used in all functional speech styles) and neoplasms characteristic of a certain style. For example, in V. Kostikov's article "I find out cute by gait... How did the Russians look and look abroad? "The following innovations are used: lexical neologism «серпастые» паспорта», combinable neologism «хорошие русские» on a certain category of Russians abroad), jargons «братки» (about bandits), «бабло» (about money), individual-author neologism «незавершенка» (on the transition period in the market economy). The main purpose of the journalistic style is the formation of public opinion. 
CURRENT RESEARCH JOURNAL OF PHILOLOGICAL SCIENCES 2(11):

80-83, November 2021

DOI: https://doi.org/10.37547/philological-crjps-02-11-18

ISSN 2767-3758

(C)2021 Master Journals

Crossref doi

\section{DissCusion}

It is known that the prototype of modern journalism was business correspondence. The language of the newspaper has long been criticized not only by journalists, but also by writers and linguists. However, in today's texts, compared to the texts of the "stagnation" period, there is a decrease in speech stamps.

Judging by the modern press, standardized elements faded into the background, giving way to expression and emotionality. The vocabulary of the journalistic style is inherent in stylistic wealth and thematic diversity. The characteristic features of the language of today's media are "Americanization," following the speech fashion, a conscious departure from the literary norm of the language. But the leading features were intertextuality, irony and language play. This is most actively used in headers. Frequent use of these techniques leads to intensive formation and use of neologisms.

Due to the constant development of society, numerous and unprecedented discoveries in the field of science and technology, the language is replenished with a huge number of new words (neologisms), which entails the need to describe and systematize them. Examples of modern innovations are linguistic neologisms. Speaking about the place of neologism in the language of the press, it is worth noting that a significant part of them are found in business, specialized and youth publications.

So, new words are created on the basis of existing word-forming models of the language, replenishing and expanding its vocabulary. These words actually exist in the language and are fixed by dictionaries. However, the creation of new words is not only, and not always, aimed at meeting the needs of society in expressing new concepts. In speech, both orally and in writing, words constantly arise that do not express at all something new, any new concept or idea. Very often, words are created that convey concepts that already exist in this language, but are expressed by other language means. Similar units (words or phrases) are formed in this case for a given context, expressing to a large extent the author's attitude to the statement. These words, unlike various words of the language, are traditionally called potential. According to the representation in linguistics, in most cases potential words are created by individual authors explicitly for stylistic purposes, to create a certain stylistic effect. Therefore, some linguists attribute all new words created in the language to the category of stylistic words.

Potential words are non-traditional words that are not fixed in the language, but possible words whose appearance is explained by the need for an appropriate name. So, for example, the word moon rover arose when a corresponding situation really arose, a ready-made model for the implementation of this potential already existed in the language (land rover). The time will come, the words rover, venereus will appear. But so far they are in the potential of the language, since there is really no need for such names.

The term (potential words) was proposed by Professor G.O. Vinokur and Professor A.I. Mirnitsky. They understood this term somewhat differently. If for G.O. Vinokur potential words are such words that actually do not exist, but which could be, which, as it were, live a subversive life in the language, then for A.I. Mirnitsky a potential word is both a word that can be formed and a word that, having arisen due to word-forming potency, can become a word of the language (lexical unit of the language system). 
CURRENT RESEARCH JOURNAL OF PHILOLOGICAL SCIENCES 2(11):

80-83, November 2021

DOI: https://doi.org/10.37547/philological-crjps-02-11-18

ISSN 2767-3758

(C)2021 Master Journals

Crossref do

81 Google

Accepted $25^{\text {th }}$ November, 2021 \& Published $30^{\text {th }}$ November, 2021

G.O. Vinokur noted: "In each language, along with words used in everyday practice, There are also some kind of "potential words," that is, words that are virtually absent, but which could have been if the historical accident wanted it.... Then, that lives in a language with a false life, which is not in the current speech, but given as a hint in the language system, breaks out in similar manifestations of linguistic innovation, turning the potential into actual. "

Having taken the idea of the possibility of the existence of a number of entities embedded in the language system, researchers developed it further. So, V.N. Kholocheva noted: "Inside the lexical system of the language, there is a contrasting manifest in the most general form: real words, i.e. functioning in the language as finished lexical units, and potential words, i.e. words that can be created in the language at any time according to the current model. Sometimes words created in this way begin to be reproduced, become units of language... Fundamentally, each word from the potential class can become a unit of language. "

Attention is drawn to the fact that the followers of the point of view of G.O. Vinokur emphasize only the possibility of the real emergence of potential words if there is a social need for them (direct or indirect). This tradition was continued by N.Z. Kotelova. Based on the data of neography, she showed that, both from a theoretical and practical point of view, the mixing of potential words and real existing ones is incorrect, since only functioning, social practice can implement the word in its unique, often unpredictable form. With potential words, she considered potentially existing words in the language, that is, having only a place, a position in the language system, but not implemented in speech. She rightly noticed that only the uzus implements the system, makes the potential real, it can be fixed and non-system.
Everything is decided by public practice, and not by the capabilities of the system. The course of derivation in a real situation can be different, since the language develops in the practice of its use. Therefore, the fate and appearance of the word cannot be predicted in advance.

E.I. Hanpira: "I call a word that can be formed from a language model of high productivity, and such a word that has already arisen from such a model, but has not yet entered the language... The term "potential" emphasizes the task of such a word by the word system of the language. "

\section{Conclusion}

First of all, it should be added to the above definition that potential words are formed according to highly productive word-forming models without any violations or deviations from the norms of formal or semantic combination of the components of the resulting word. For this reason, potential words are not distinguished among other words, they do not feel novelty or unusual. These features justify the separation of such words into an independent category.

Many potential words are gradually updated in the language, enter the norm, and thereby expand it. For example, the verbs "voice" and "digitize" can already be included among the quite normative lexical units, which, 10-15 years ago, were just potential words. And on the approach there are many more words formed according to the same model and already finding use in speech (for example, on the Internet there are about 600 cases of using the verb "осетить" and about 500 "обуютить", and this statistic refers only to the infinitive).

осЕтить - move to the network, hang, publish to the network.

Можно осетить: роман, журнал, бумажные издания, книгу, бизнес, полемику, дискуссию, 
CURRENT RESEARCH JOURNAL OF PHILOLOGICAL SCIENCES 2(11):

80-83, November 2021

DOI: https://doi.org/10.37547/philological-crjps-02-11-18

ISSN 2767-3758

(C2021 Master Journals

\section{Crossref do) 810 Google}

Accepted $25^{\text {th }}$ November, 2021 \& Published $30^{\text {th }}$ November, 2021

агентство, проблему, выборы...

«Твой бизнес давно пора осетить, он не может двигаться только бумажной рекламой».

обуЮтить - сделать уютным, придать уютности.

«Как нам обуютить Россию? - Сначала попробуй

обуютить свой дом».

ожУтить - сделать жутким, придать жуткости.

«Современная массовая культура стремится

ожутить явления, чтобы эмоционально

взбодрить психику, уже притупленную

воздействием массмедиа».

особЫтить - saturate with events, give more eventuality.

«С утра он уже начинал думать, как особытить день».

опривЫчить - make it familiar, make it a habit.

«Чтобы опривычить ремни безопасности, пришлось ввести штраф».

Also, potential words are close to occasionalisms: хваталка, погонялка, пускалка, хлопалка and others.

An important difference between occasionalisms and potential words is that occasionalisms are "violators of the laws (rules) of general language word formation," and potential words, on the contrary, "filling empty cells of word-forming paradigms... implement the laws of word formation. " Occasionalisms and potential words are often found in spontaneous colloquial speech: the word created on occasion - in accordance with the laws of word formation or contrary to them - the speaker often means either that he does not have a standard name, or that he cannot immediately recall the regular designation.

\section{REFERENCES}

1. Avilova S.N. Words of international origin in the Russian literary language of the new time. M., "Science," 1967.

2. Bragina A.A. Neologisms in Russian. -M.:
Science, 1973. - 224 pages.

3. Vinogradova N.V. Computer slang and literary language: competition problems. Studies on Slavic languages. No. 6.- Seoul, 2001. S.203-216.

4. Voloshin Yu.K. Novoformations and the actual neologisms of the modern English language: autoref. diss. Candidate of Philol. Sciences/Yu.K. Voloshin; Mosk. ped. in-t named after V.I. Lenin. M, 1971. - $16 \mathrm{~s}$.

5. Popova T.V. Russian neology and neography. Tutorial electronic text edition. Yekaterinburg. 1996. 96 pages.

6. Rasuljanovna, I. N. (2019). The phenomenon of lacunarity as the linguacultural issue. Prospects of world science-2019, 226.

7. Ismatullayeva, N. R. (2013). Texts of Lectures in the Subject of Synchronous Translation. Tashkent SIOS, Department of Translation Theory and Practice Tashkent, 2013-55 p. 